\title{
A Systematic Review of the Potential Effects of Nigella sativa on Rheumatoid Arthritis
}

\author{
Authors \\ Affiliations \\ 1 Connective Tissue Diseases Research Center, Tabriz \\ University of Medical Sciences, Tabriz, Iran \\ 2 Department of Health Education \& Promotion, Faculty of \\ Health, Tabriz University of Medical Sciences, Tabriz, Iran \\ 3 School of Biotechnology and Biomolecular Sciences, \\ Faculty of Science, University of New South Wales, Sydney, \\ Australia
}

Alireza Khabbazi ${ }^{1}$, Zeinab Javadivala ${ }^{2}$, Neda Seyedsadjadi ${ }^{3}$, Aida Malek Mahdavi ${ }^{1}$

\section{ABSTRACT}

Key words

Nigella sativa, Ranunculaceae, thymoquinone, rheumatoid arthritis

$\begin{array}{ll}\text { received } & \text { November 8, } 2019 \\ \text { revised } & \text { March 20, } 2020 \\ \text { accepted } & \text { March 20, } 2020\end{array}$

Bibliography

DOI https://doi.org/10.1055/a-1143-8521

published online April 9, 2020 | Planta Med 2020; 86: 457469 @ Georg Thieme Verlag KG Stuttgart · New York | ISSN 0032-0943

\section{Correspondence}

Aida Malek Mahdavi, Ph. D.

Assistant Professor of Nutrition Sciences, Connective Tissue Diseases Research Center, Imam Reza Medical Research \& Training Hospital, Tabriz University of Medical Sciences Golgasht St. 4, P. O. Box 5166614756,

5166/15731 Tabriz, Iran

Phone: + 984133369331 , Fax: + 984133369315

aidamalek@gmail.com
Considering the different untoward effects of the drugs prescribed for the treatment of rheumatoid arthritis (RA), there has been an increasing interest in adjuvant therapies devoid of such unfavorable reactions. Although the beneficial effects of Nigella sativa ( $N$. sativa) on RA have been established, it seems that its mechanisms of action have not still been reviewed. The present review is designed to evaluate the effects of $N$. sativa on RA systematically. We searched these electronic databases until April 2019: PubMed, Scopus, ISI Web of Science, Cochrane Library, Embase, Ovid, ProQuest, and Google scholar. No restriction was conducted based on language or publication date. We selected all of the related clinical, animal, and in vitro studies. Review papers, abstracts in conferences, book chapters, and papers regarding the effects of $N$. sativa combined with other herbs, as well as articles regarding the effects of $N$. sativa on other diseases, were excluded. Each article was assessed critically for the possible risk of bias. Nineteen articles were reviewed. Animal and in vitro investigations supported the favorable effects of $N$. sativa on clinical, inflammatory, oxidative, and immunologic parameters on RA, whereas results of limited clinical studies did not illustrate any change or improvement of inflammatory and oxidative biomarkers in RA. N. sativa could control RA via multiple ways such as decreasing inflammation, inhibiting oxidative stress, and modulating the immune system. This paper provides persuasive clues to defend the efficacy of $N$. sativa in RA and justifies the significance of subsequent clinical trials.

\section{Introduction}

Rheumatoid arthritis (RA) is a chronic ailment specified with an immune system disturbance and inflammation of the synovium, causing articular pain and stiffness, bone and cartilage destruction, disability, and deformity as well as systemic complications such as cardiovascular, pulmonary, and psychological problems [1]. RA is the most common inflammatory arthritis that is prevalent in $0.5-1 \%$ of world population with a 3 -time greater incident in women than men [2]. This disease significantly leads to diminished quality of life and functional capacity together with increased morbidity and mortality rates and imposes remarkable costs for the health and social care systems [3]. - Fig. 1 presents the pathogenic pathways of RA.

Several pharmaceutical therapies have been suggested and marketed for RA treatment including nonsteroidal anti-inflammatory drugs (NSAIDs), nonbiologic and biologic disease-modifying antirheumatic drugs (DMARDs), immunosuppressants, and corticosteroids. However, as these medications are mostly accompanied by various side effects [4], in recent $y$, there has been an increasing interest in adjuvant therapies devoid of such unfavorable effects.

Medicinal herbs have gained a lot of attention recently and have been used all over the world to treat various diseases [5]. 


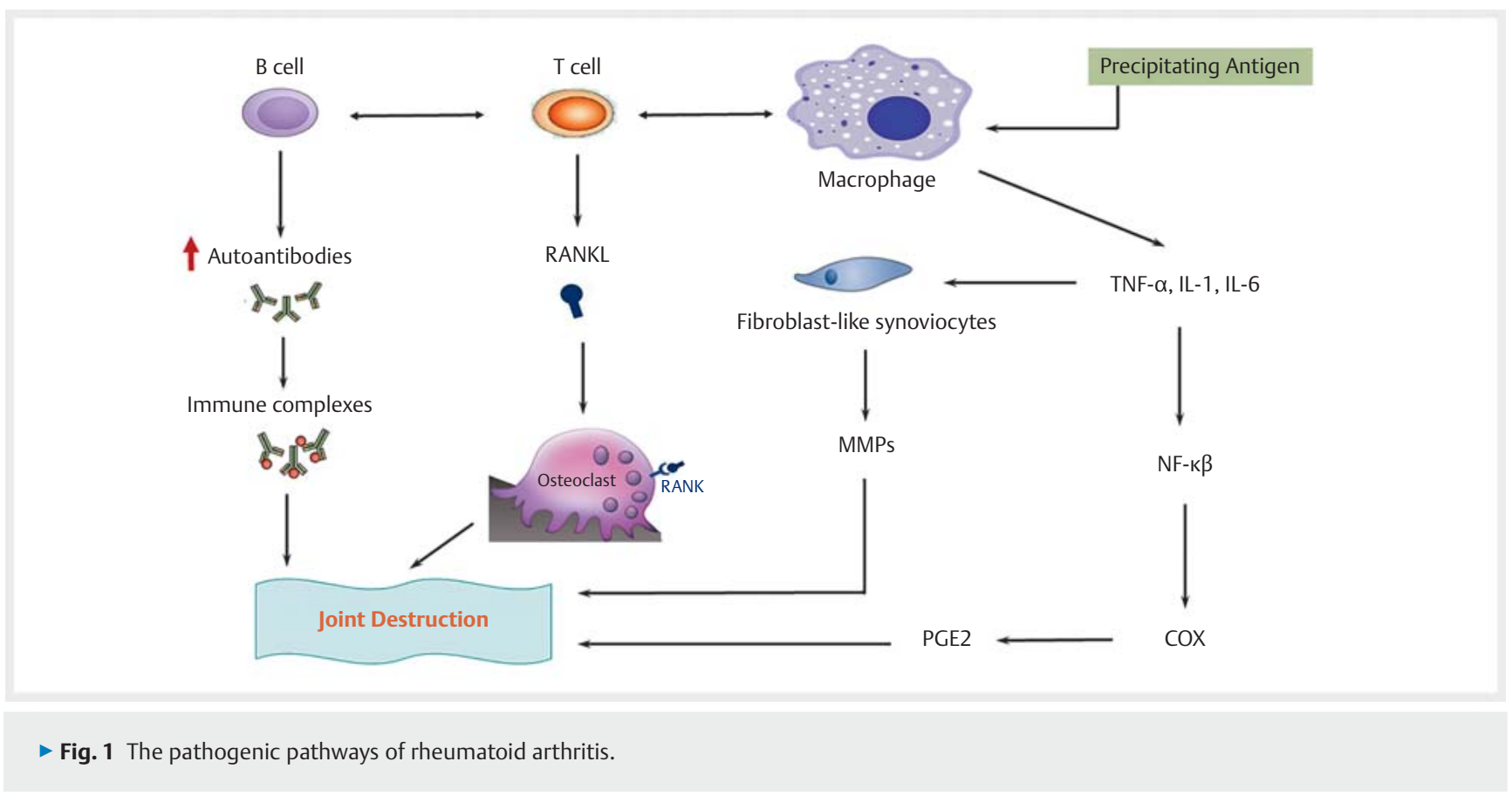

There is growing evidence in the literature on how some of these medicinal herbs can be effective in the treatment of RA symptoms [6]. One such promising plant is Nigella sativa L. (N. sativa) (family Ranunculaceae), usually known as black seed [7]. N. sativa has been consumed customarily in the Middle and Far East and South Asian countries for the treatment of different disorders [7]. Traditional uses of $N$. sativa derive from the ancient Egyptians, Greeks, and Romans [8]. The Islamic prophet Mohammed is said to have referred to this herb as having healing capacities for every ailment except death [9]. N. sativa has been favored by Ibn Sina (Avicenna) as a remedy for fever, headache, toothache, and common cold [10]. It is also proposed as a sedative for skin disorders, wounds, and external irritations [10]. In folklore medicine, $N$. sativa seeds and oil have been regularly prescribed as a natural remedy for various diseases such as fever, cough, nasal congestion, bronchitis, asthma, dyspnea, hypertension, diabetes mellitus, inflammation, eczema, dizziness, gastrointestinal problems, and pain conditions $[11,12]$. Furthermore, N. sativa has multiple biological and pharmacological functions including antioxidant [13-15], anti-inflammatory and analgesic $[16,17]$, anticancer $[18,19]$, antimicrobial $[20,21]$, immune enhancement [22,23], hypoglycemic [24], hypotensive [25], hypolipidemic and cardioprotective [26-28], hepato-protective, gastro-protective $[29,30]$, renal-protective [31,32], spasmolytic, bronchodilator [33-35], and increased milk production [36]. Moreover, N. Sativa has been beneficial for convulsion [37, 38], depression [39], men's infertility [40], and memory improvement [41]. Most of the therapeutic characteristics of $N$. sativa are attributable to the thymoquinone (TQ), a major active component and a phytochemical present in the essential oil [42]. Other components of $N$. sativa seed include carbohydrates, amino acids, proteins, both essential and fixed oil, sterols, alkaloids, saponins, organic acids, crude fiber, vitamins, and minerals [43]. The chemical structures of TQ and other chemical constituents found in $N$. sativa seed and oil are illustrated in $>$ Fig. 2. Fur- thermore, human [44] and animal models [45] have not shown any critical undesirable results.

The beneficial effects of $N$. sativa on RA prevention and treatment have been investigated in recent $y$, and some hopeful findings have been obtained from experimental investigations [4651] and clinical trials [52-56]. It has been suggested that $N$. sativa can influence the main traits of RA via various procedures [57]. Even though some review papers have been published regarding the medicinal features of N. sativa [58-60], to the authors' knowledge, there has not been any review conducted in the area of $N$. sativa and RA. Therefore, in this research, we aimed to conduct a systematic study on the available literature regarding the effects of $N$. sativa on RA in clinical, animal and cellular models and possible mechanisms responsible for such effects.

\section{Materials and Methods}

\section{Protocol and registration}

The current systematic literature search was performed according to the preferred reporting items for systematic reviews and metaanalysis guidelines [61]. The study protocol can be observed on the international prospective register of systematic reviews (PROSPERO) database (http://www.crd.york.ac.uk/PROSPERO, registration No: CRD42019133047).

\section{Search Strategy and Article Selection}

We searched the following electronic databases until April 2019: PubMed, Scopus, ISI Web of Science, Cochrane Library, Embase, Ovid, ProQuest, and Google scholar. The MESH and nonMESH search terms applied were ("Nigella sativa" OR "sativa, Nigella" OR “N. sativa” OR "Black Cumin" OR "Cumin, Black" OR "black seed” OR Kalonji OR "black caraway” OR thymoquinone) AND ("Arthri- 
<smiles>CC1=CC(=O)C(C(C)C)=CC1=O</smiles>

Thymoquinone<smiles>Cc1cc(O)c(C(C)C)cc1O</smiles>

Thymohydroquinone<smiles>Cc1ccc(C(C)C)c(O)c1</smiles>

Thymol<smiles></smiles>

Dithymoquinone<smiles>COc1cc2ccnc(C)c2cc1OC</smiles>

Nigellimine<smiles>Cc1cc(O)c2c(C(=O)O)[n+]3n(c2c1)CCCC3</smiles>

Nigellicine<smiles>Cc1cc2n3n(c(-c4ccc(O)cc4)c-2c(=O)c1)CCCC3</smiles>

Nigellidine<smiles>Cc1ccc(C(C)C)cc1</smiles>

p-Cymene<smiles>CC1=CCC2CC1C2(C)C</smiles>
alpha-Pinene<smiles>Cc1ccc(C(C)C)cc1O</smiles>

Carvacrol<smiles>C=C(C)C1CC=C(C)CC1</smiles>

Limonene<smiles>COCOC1C(OC2CCC3(C)C(CCC4(C)C3CC=C3C5CC(C)(C)CCC5(C(=O)O)CCC34C)C2(C)CO)OCC(O)C1O</smiles>

- Fig. 2 The chemical structures of thymoquinone and other chemical constituents found in N. sativa seed and oil.

tis, Rheumatoid" OR “Rheumatoid Arthritis" OR RA OR Rheumatoid OR Arthritis). No restriction was conducted based on language or publication date. Two authors (A.KH. and A. M. M.) independently searched, screened, and extracted the data. Duplicated studies were then eliminated. In general, these 2 authors had an agreement on selecting the studies, and possible variations were removed by the third author (Z.J.).

We selected all of the related clinical, animal, and in vitro studies. We also checked the references of selected papers to identify possible novel investigations. In addition, we used search alert services in order to identify any relevant article published after the primary search. Review papers, abstracts in conferences, book chapters, and papers regarding the effects of $N$. sativa combined with other herbs on RA were not included. Also, papers regarding the effects of N. sativa in other diseases were not included. Considering the specified search terms and the inclusion criteria, 18 papers were assessed. Furthermore, 1 article published after the initial search was identified via search alert services and reviewed. - Fig. 3 presents the flowchart of screening and choosing papers.

\section{Data extraction}

Two independent reviewers (A.KH. and A.M.M.) extracted data from the eligible papers. The following information was obtained from the papers: first author's name, publication y, location, subject features, type and dosage of $N$. sativa supplement, treatment duration, and main results of studies. Any probable controversies were removed with the third reviewer (Z.J.). A summary of the included studies is presented in $>$ Tables $\mathbf{1 - 3}$. 


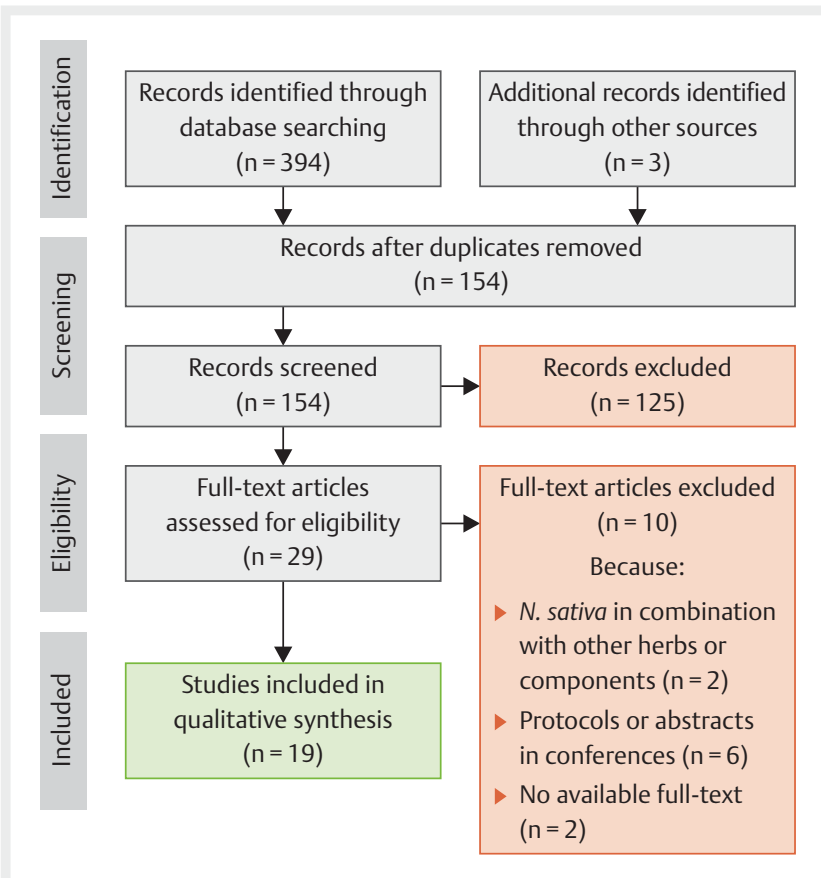

- Fig. 3 The flowchart of screening and choosing eligible articles.

\section{Assessment of risk of bias}

Each of the qualified papers was evaluated for the potential risk of bias using Cochrane Collaboration's tool [62] for clinical studies, Checklist for Reporting In vitro Studies (CRIS) Guideline [63], for in vitro studies and SYRCLE's risk of bias tool [64] for animal studies. The SYRCLE's risk of bias tool is based on the Cochrane Rob tool and has been adapted for aspects of bias that have a particular function in animal intervention. Both of the tools have 6 domains ( $\bullet$ Fig. 4), and each domain was evaluated as having a low, unclear, or high risk of bias.

\section{Results}

\section{Study characteristics}

We identified 397 related papers. After removing duplicates, 154 papers remained that were screened by reviewing both titles and abstracts. Of those, 125 papers were excluded after the revision. Eventually, out of 29 potentially relevant publications, 10 studies were removed for the following reasons: $N$. sativa had been combined with other herbs or components $(n=2)$, they were protocols or abstracts in conferences $(n=6)$, and there was no available full-text $(n=2)$. Finally, 19 papers were entered in the systematic review ( $\triangleright$ Fig. 3 ). The entered studies were classified into clinical $(n=5)$, animal $(n=13)$ and in vitro $(n=3)$ studies.

- Table 1 Characteristics of human studies regarding the effect of Nigella sativa on rheumatoid arthritis.

\begin{tabular}{|c|c|c|c|c|c|c|}
\hline Author (date) & Country & Subjects & Intervention & Dosage & Duration & Results \\
\hline $\begin{array}{l}\text { Hadi et al. } \\
\text { (2016) [55] }\end{array}$ & Iran & $\begin{array}{l}\text { Female RA patients } \\
\text { ( } \mathrm{n}=25 \text { per group) }\end{array}$ & $\begin{array}{l}\text { Nigella sativa } \\
\text { oil capsules }\end{array}$ & $1 \mathrm{~g} /$ day & $8 w k$ & $\begin{array}{l}\text { 1. Significant decrease in DAS28 score compared } \\
\text { with the placebo group. } \\
\text { 2. No significant differences in serum IL-10, } \\
\text { TNF- } \alpha \text {, MDA, SOD, catalase, TAC, and NO } \\
\text { compared with the placebo group. }\end{array}$ \\
\hline $\begin{array}{l}\text { Kheirouri } \\
\text { et al. (2016) } \\
\text { [52] }\end{array}$ & Iran & $\begin{array}{l}\text { Female RA patients } \\
\text { ( } \mathrm{n}=25 \text { per group) }\end{array}$ & $\begin{array}{l}\text { Nigella sativa } \\
\text { oil capsules }\end{array}$ & $1 \mathrm{~g} /$ day & $8 w k$ & $\begin{array}{l}\text { 1. Significant reduction in } \mathrm{DAS} 28 \text { and } \mathrm{CD} 8^{+} \\
\text {percentage compared to the placebo. } \\
\text { 2. Significant increase in } \mathrm{CD} 4^{+} / \mathrm{CD} 8^{+} \text {ratio and } \\
\mathrm{CD} 4^{+} \mathrm{CD} 25^{+} \text {regulatory T cell percentage } \\
\text { compared to the placebo. } \\
\text { 3. No significant changes in percentage of } \\
\mathrm{CD} 4^{+} T \text { cells compared to the placebo. }\end{array}$ \\
\hline $\begin{array}{l}\text { Cheita et al. } \\
\text { (2011) [54] }\end{array}$ & Egypt & $\begin{array}{l}\text { Female RA patients } \\
(n=40)\end{array}$ & $\begin{array}{l}\text { Nigella sativa } \\
\text { oil capsules }\end{array}$ & $1 \mathrm{~g} /$ day & 4 wk & $\begin{array}{l}\text { Significant decrease in DAS28, number of swollen } \\
\text { joints, duration of morning stiffness, VAS for pain, } \\
\text { and WBC count compared to the placebo. }\end{array}$ \\
\hline $\begin{array}{l}\text { Mahdy et al. } \\
\text { (2009) [56] }\end{array}$ & Egypt & $\begin{array}{l}\text { Female R A patients } \\
(n=36)\end{array}$ & $\begin{array}{l}\text { Nigella sativa } \\
\text { oil capsules }\end{array}$ & $1 \mathrm{~g} /$ day & $2 w k$ & $\begin{array}{l}\text { Significant decrease in DAS28, RAI, morning stiff- } \\
\text { ness, and WBC count compared to the placebo. }\end{array}$ \\
\hline $\begin{array}{l}\text { Al-Okbi et al. } \\
(2000) \text { [53] }\end{array}$ & Egypt & $\begin{array}{l}\text { Male RA patients } \\
\text { ( } \mathrm{n}=28 \text { per group) }\end{array}$ & $\begin{array}{l}\text { Nigella sativa } \\
\text { oil capsules }\end{array}$ & 2 g/day & $8 w k$ & $\begin{array}{l}\text { 1. No significant changes in ESR, CRP, RF, PGE2, } \\
\text { SOD, vitamin C, vitamin E, and uric acid com- } \\
\text { pared to the other treatment groups. } \\
\text { 2. Significant decrease in plasma Cu, creatinine, } \\
\text { AST, and ALT compared to the other treatment } \\
\text { groups. } \\
\text { 3. Significant increase in plasma Zn compared } \\
\text { to the other treatment groups. }\end{array}$ \\
\hline
\end{tabular}

RA: rheumatoid arthritis; DAS: disease activity score; IL-10: interleukin-10; TNF: tumor necrosis factor; MDA: malondialdehyde; SOD: superoxide dismutase; TAC: total antioxidant capacity; NO: nitric oxide; RAl: ritchie articular index; WBC: white blood cell; VAS: visual analog scale; ESR: erythrocyte sedimentation rate; CRP: C-reactive protein; RF: rheumatoid factor; PGE2: prostaglandin E2; AST: aspartate aminotransferase; ALT: alanine aminotransferase. 







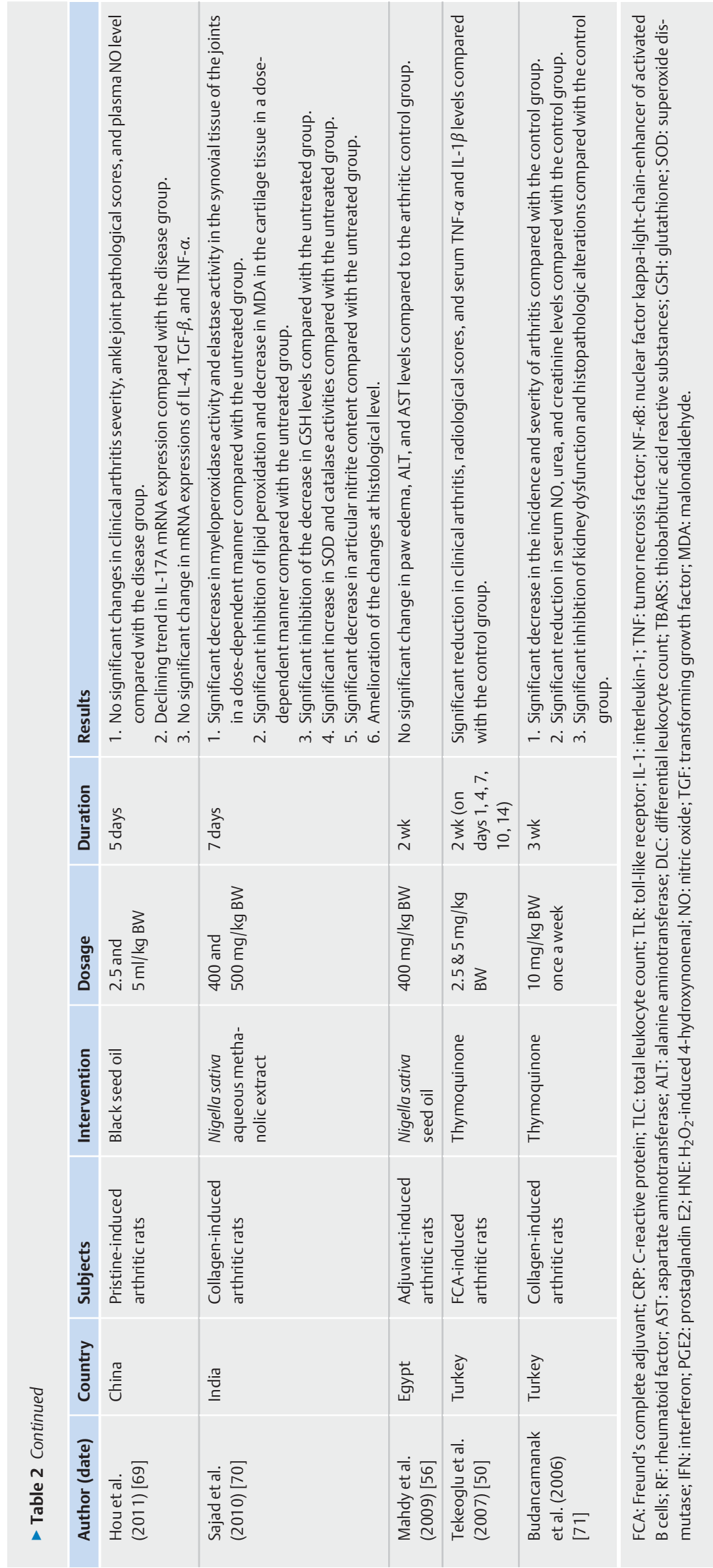


- Table 3 Characteristics of in vitro studies regarding the effect of Nigella sativa on rheumatoid arthritis.

\begin{tabular}{|c|c|c|c|c|c|c|}
\hline Author (date) & Country & Subjects & Treatment & Dosage & Duration & Results \\
\hline $\begin{array}{l}\text { Umar et al. } \\
\text { (2015) [47] }\end{array}$ & USA & $\begin{array}{l}\text { Human } \\
\text { RA synovial } \\
\text { fibroblasts }\end{array}$ & $\begin{array}{l}\text { Thymo- } \\
\text { quinone } \\
\text { (TQ) }\end{array}$ & $1-5 \mu \mathrm{M}$ & $2 \mathrm{hr}$ & $\begin{array}{l}\text { 1. Induction of apoptosis by blocking Mcl-1 expression. } \\
\text { 2. Inhibition of TNF- } \alpha \text {-induced IL-6 and IL-8 production } \\
\text { in a dose-dependent manner. } \\
\text { 3. Decrease in TNF- } \alpha \text {-induced ICAM-1, VCAM-1, } \\
\text { and Cad-11 expression. } \\
\text { 4. Inhibition of TNF- } \alpha \text {-induced phosphorylation of p38 and } \\
\text { JNK in a dose-dependent manner. } \\
\text { 5. Inhibition of TNF- } \alpha \text {-induced ASK1 activation and } \\
\text { suppression of p38/JNK-mediated phospho-c-Jun } \\
\text { expression. } \\
\text { 6. Inhibition of ASK1 phosphorylation and subsequent } \\
\text { activation to decelerate TNF- } \alpha \text { signaling. }\end{array}$ \\
\hline $\begin{array}{l}\text { Vaillancourt } \\
\text { et al. (2011) } \\
\text { [46] }\end{array}$ & Canada & $\begin{array}{l}\text { Human } \\
\text { RA fibro- } \\
\text { blast-like } \\
\text { synoviocytes }\end{array}$ & $\begin{array}{l}\text { Thymo- } \\
\text { quinone } \\
\text { (TQ) }\end{array}$ & $0-10 \mu \mathrm{M}$ & $1 \mathrm{hr}$ & $\begin{array}{l}\text { 1. Moderate antiproliferative (inhibition of cell growth by } \\
20 \% \text { ) and strong antioxidative effects (prevention of HNE } \\
\text { generation up to } 70 \% \text { ). } \\
\text { 2. Inhibition of the LPS-induced mRNA expression of IL-1 } \beta \\
\text { and TNF- } \alpha \text {. } \\
\text { 3. Inhibition of the LPS-induced PGE } 2 \text { release and COX-2 } \\
\text { expression in a dose-dependent manner. } \\
\text { 4. Prevention of LPS-induced MMP-13 expression at the } \\
\text { protein and mRNA levels in a dose-dependent manner. } \\
\text { 5. Inhibition of LPS-induced p38 MAPK, ERK } 1 / 2 \text {, and } \\
\text { NF-KB-p65 phosphorylation and their signaling path- } \\
\text { ways. }\end{array}$ \\
\hline $\begin{array}{l}\text { May et al. } \\
(2007) \text { [72] }\end{array}$ & USA & $\begin{array}{l}\text { HTB-93 } \\
\text { Female } \\
\text { RA Cell Line }\end{array}$ & $\begin{array}{l}\text { Thymo- } \\
\text { quinone } \\
\text { (TQ) }\end{array}$ & $\begin{array}{l}10,50 \\
100 \mu \mathrm{M}\end{array}$ & $\begin{array}{l}24,48, \\
72 \mathrm{hr}\end{array}$ & $\begin{array}{l}\text { 1. Significant reduction in cell proliferation and cell number } \\
\text { compared to the controls. } \\
\text { 2. No significant change in MDA levels compared to the } \\
\text { controls. } \\
\text { 3. Significant changes in total cellular protein levels. } \\
\text { 4. Significant increase in glutathione levels only at high- } \\
\text { dose treatment }(100 \mu \mathrm{M}) \text { at } 72 \mathrm{~h} \text { compared to the } \\
\text { control. } \\
\text { 5. No significant change in glutathione levels at doses } \\
\text { of } 10-50 \mu \mathrm{M} \text { treatment over } 24,48 \text {, and } 72 \mathrm{~h} \text { compared } \\
\text { to the control. } \\
\text { 6. Significant decrease in NO levels over } 24 \mathrm{~h} \text { treatment } \\
\text { compared to the control. } \\
\text { 7. No significant change in NO production over } 48 \text { and } 72 \mathrm{~h} \\
\text { compared to the control. }\end{array}$ \\
\hline
\end{tabular}

RA: rheumatoid arthritis; MCL: myeloid cell leukemia; ICAM: intercellular adhesion molecule; VCAM: vascular cell adhesion molecule; CAD: cadherin; ASK: apoptosis-regulated signaling kinase; JNK: c-Jun N-terminal kinase; LPS: lipopolysaccharides; $\mathrm{HNE}$ : $\mathrm{H}_{2} \mathrm{O}_{2}$-induced 4-hydroxynonenal; PGE2: prostaglandin E2; COX: cyclooxygenase; MMP: matrix metalloproteinase; MAPK: mitogen-activated protein kinase; ERK: extracellular-signal-regulated kinase; NF-kB: nuclear factor kappa-light-chain-enhancer of activated B cells; MDA: malondialdehyde; NO: nitric oxide.

One study included both human and animal models [56], and 1 study included both animal and in vitro models [46]. Characteristics of the investigations are demonstrated in - Tables 1-3.

\section{Human studies}

The effect of $N$. sativa consumption on RA cases was assessed in 5 investigations only ( $\triangleright$ Table $\mathbf{1}$ ). In a research by Hadi et al. [55] on 50 female RA patients, $N$. sativa oil supplementation ( $1 \mathrm{~g} /$ day) for 8 wk caused a significant decrease in disease activity score 28 (DAS28) compared with the placebo group, while there were no considerable differences in serum interleukin-10 (IL-10), tumor necrosis factor- $\alpha$ (TNF- $\alpha$ ), malondialdehyde (MDA), superoxide dismutase (SOD), catalase, total antioxidant capacity (TAC), and nitric oxide (NO) between the groups. Furthermore, in a study by
Kheirouri et al. [52] on 50 female RA patients, $N$. sativa oil supplementation ( $1 \mathrm{~g} /$ day) for $8 \mathrm{wk}$ led to a significant reduction in DAS28 and $\mathrm{CD}^{+}$percentage and a significant increase in $\mathrm{CD}^{+} / \mathrm{CD}^{+}$ratio and $\mathrm{CD} 4^{+} \mathrm{CD} 25^{+}$regulatory $\mathrm{T}$ cell percentage compared to the placebo, while there were no considerable differences in percentage of $C D 4^{+} T$ cells. In a study by Gheita et al. [54] on 40 female patients with RA, N. sativa oil supplementation $(1 \mathrm{~g} /$ day) for 4 wk caused a significant decrease in DAS28, number of swollen joints, morning stiffness duration, visual analog scale (VAS) for pain, and white blood cell (WBC) count compared to the placebo. Another study by Mahdy et al. [56] on 36 female RA patients indicated that $N$. sativa oil supplementation ( $1 \mathrm{~g} /$ day) for 2 wk caused a significant decrease in DAS28, Ritchie articular index (RAI), morning stiffness, and white blood cell cin comparison 


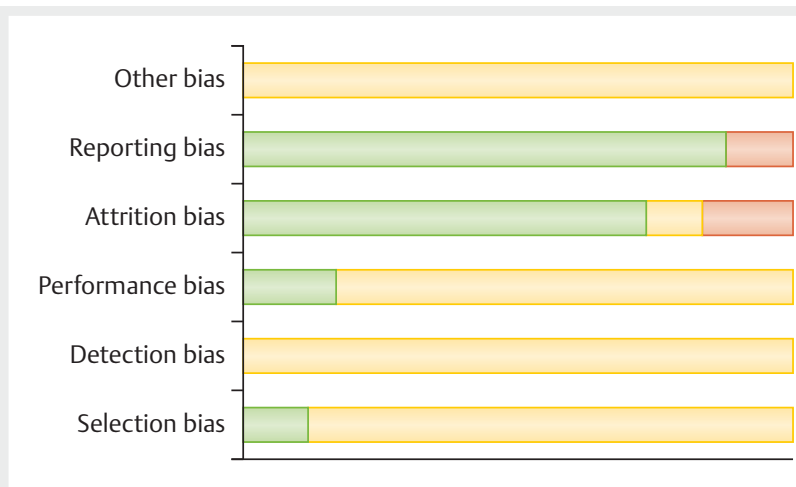

Low risk of bias $\square$ Unclear risk of bias $\square$ High risk of bias

- Fig. 4 The risk of bias assessment across the studies $(n=21)$.

with the placebo. In a research by Al-Okbi et al. [53] on 56 male RA patients, $N$. sativa oil supplementation ( $2 \mathrm{~g} /$ day) for $8 \mathrm{wk}$ led to a remarkable reduction in plasma $\mathrm{Cu}$, creatinine, aspartate aminotransferase (AST), and alanine aminotransferase (ALT) and a significant increase in plasma $\mathrm{Zn}$, compared to the other treatment groups, whereas there were no significant changes in erythrocyte sedimentation rate (ESR), C-reactive protein (CRP), rheumatoid factor (RF), prostaglandin E2 (PGE2), SOD, vitamin C, vitamin E, and uric acid compared to the other treatment groups.

\section{Animal studies}

Several animal investigations supported the effect of $N$. sativa on RA ( $\vee$ Table 2). According to the inclusion criteria, 13 animal investigations were entered in the current systematic review. Arjumand et al. [48] reported that $10 \mathrm{mg} / \mathrm{kg}$ BW TQ caused a considerable reduction in the arthritic score and CRP levels, significant normalization of total leukocyte count (TLC), lymphocytes, neutrophils, and monocytes; significant alleviation of inflammation, pannus formation, and bone erosion; and a significant decrease in mRNA expression levels of toll-like receptor (TLR)2, TLR4, IL-1, nuclear factor kappa-light-chain-enhancer of activated $B$ cells (NF- $k$ B), and TNF- $\alpha$ in rats with Freund's Complete Adjuvant-induced arthritic compared to the arthritic control group, while there was no significant change in RF compared to the arthritic control group. Nasuti et al. [65] noted that N. sativa oil administration (1596 and $798 \mathrm{mg} / \mathrm{kg}$ BW for 25 days) contributed to significant alleviation in paw volume and had significant antinociceptive activity in contralateral hind paw in Freund's Complete Adjuvant-induced arthritic rats compared to the arthritic control group; however, reduction in paw volume and the arthritis score was not significant compared to the arthritic control group. Moreover, no considerable change occurred in \% of inhibition of arthritis, spontaneous locomotor activity, plasma levels of IL-6, CRP, and albumin compared to the arthritic control group. Additionally, no significant antinociceptive activity was reported in the inoculated hind paw compared to the arthritic control group [65]. Another study in Freund's Complete Adjuvant-induced arthritic rats also indicated that TQ (2.5 and $5 \mathrm{mg} / \mathrm{kg} \mathrm{BW}$ ) led to a significant reduction in clinical arthritis, radiological scores, and serum
TNF- $\alpha$ and IL- $1 \beta$ levels in comparison with the control group [50]. Faisal et al. [66] reported that administering TQ (2 mg/ $\mathrm{kg} \mathrm{BW})$ for 15 days to pristine-induced arthritic rats significantly decreased paw weight and score of histopathological parameters (e.g., inflammatory cells, synovial hyperplasia, villous hyperplasia, and pannus formation) compared to the arthritic control group. Furthermore, they showed a considerable decrease in TLC, clinical score of inflammation, and number of inflammatory cells as well as improvement in blood urea and serum creatinine and normalization of differential leukocyte count (DLC) compared to the arthritic control group $[49,67,68]$. Another study in pristine-induced arthritic rats [69] indicated that 2.5 and $5 \mathrm{ml} / \mathrm{kg}$ BW black seed oil did not cause significant changes in clinical arthritis severity, ankle joint pathological scores, and plasma NO level compared with the disease group. There was no significant change in mRNA expressions of IL-4, transforming growth factor (TGF)- $\beta$, and TNF- $\alpha$; however, a declining trend in IL-17A mRNA expression was observed compared with the disease group. In a study in collagen-induced arthritic rats, Umar et al. [51] found that $5 \mathrm{ml} / \mathrm{kg}$ BW TQ for 21 days lowered the severity and the development of collagen-induced arthritis in a dose-dependent manner and resulted in a significant decrease in articular elastase and myeloperoxidase concentrations, neutrophil activation, and infiltration in the synovial tissues of the joints, as well as a significant decrease in thiobarbituric acid reactive substances (TBARS) level in the cartilage tissue compared with the untreated disease group. In addition, TQ considerably prevented down-regulation of glutathione (GSH) and SOD and replenished catalase activity compared with the untreated disease group [51]. Also, TQ significantly decreased nitrite concentration, suppressed the increase in IL-1 $\beta$, IL-6, TNF- $\alpha$, interferon (IFN)- $\gamma$, and PGE2 levels, and enhanced IL10 levels compared with the untreated diseased group. Furthermore, it improved the changes at the histological level and restored the degenerative changes [51]. Another study in collageninduced arthritic rats showed that the administration of 400 and $500 \mathrm{mg} / \mathrm{kg}$ BW N. sativa aqueous methanolic extract led to a significant decrease in myeloperoxidase and elastase activities in the joints as well as a significant suppression of lipid peroxidation and a decrease in MDA in the cartilage tissue in a dose-dependent manner compared with the untreated group [70]. Moreover, $N$. sativa aqueous methanolic extract significantly restored $\mathrm{GSH}$ levels, increased SOD and catalase activities, and decreased articular nitrite content compared with the untreated group. It also improved the changes at histological level [70]. Moreover, Budancamanak et al. [71] stated that giving $10 \mathrm{mg} / \mathrm{kg}$ BW TQ by gavage for 3 wk to collagen-induced arthritic rats can cause a significant reduction in the incidence and severity of arthritis, serum NO, urea, and creatinine levels. It can also inhibit kidney dysfunction and histopathologic alterations significantly compared to the control group. In a study in adjuvant-induced arthritic rats, $400 \mathrm{mg} / \mathrm{kg}$ BW N. sativa seed oil for 2 wk did not cause a significant change in paw edema, ALT, and AST levels compared to the arthritic control group [56]. TQ administration (5 mg/kg BW) by oral gavage has also been shown to cause a significant reduction in serum $\mathrm{H}_{2} \mathrm{O}_{2}$-induced 4-hydroxynonenal (HNE), IL-1 $\beta$, TNF- $\alpha$, PGE2, and bone turnover markers such as alkaline phosphatase and tartrate-resistant acid phosphatase [46]. TQ was also able to 
inhibit significantly the arthritis score elevation and paw swelling compared to the arthritic control group [46].

\section{In vitro studies}

Findings from in vitro studies supported the effect of $N$. sativa on RA via showing moderate antiproliferative and strong anti-inflammatory and antioxidant features of TQ ( $\bullet$ Table 3 ). These results indicate that the treatment of human RA synovial fibroblasts with $1-5 \mu \mathrm{M}$ TQ can induce apoptosis by blocking myeloid cell leukemia (Mcl)- 1 expression and inhibit TNF- $\alpha$-induced IL-6 and IL-8 generation in a dose-dependent style. TQ treatment can additionally decrease levels of TNF- $\alpha$-induced intercellular adhesion molecule (ICAM)- 1 and vascular cell adhesion molecule (VCAM)-1, reduce the expression of cadherin (Cad)-11, and inhibit TNF- $\alpha$-induced phosphorylation of p38 and c-Jun N-terminal kinase (JNK) in a dose-dependent style. TQ treatment has also been illustrated to prevent the phosphorylation and the subsequent activation of TNF- $\alpha$-induced apoptosis-regulated signaling kinase (ASK)- 1 to decelerate TNF- $\alpha$ signaling and to suppress the expression of p38/JNK-mediated phospho-c-Jun [47]. Vaillancourt et al. [46] suggested that treatment with $0-10 \mu \mathrm{M}$ TQ in human RA fibroblast-like synoviocytes can inhibit the lipopolysaccharides (LPS)induced mRNA expression of IL- $1 \beta$ and TNF- $\alpha$, PGE2 release, and cyclooxygenase (COX)-2 expression and prevent LPS-induced matrix metalloproteinase (MMP)-13 expression at the protein and mRNA levels in a dose-dependent style. The authors further reported the inhibition of LPS-induced p38 mitogen-activated protein kinase (MAPK), extracellular-signal-regulated kinase (ERK 12 ) and NF-KB-p65 phosphorylation and their signaling pathways [46]. In a study by May et al. [72] in HTB-93 female RA Cell Line, TQ treatment $(10,50$, and $100 \mu \mathrm{M})$ caused a significant reduction in cell proliferation, cell number, and NO levels compared to the controls. A significant decrease and/or increase in total cellular protein levels, and a significant increase in GSH levels compared to the controls were also reported; while no significant change in MDA levels and NO production were shown [72].

\section{Methodological quality and risk of bias}

The risk of bias was evaluated for all of the above-mentioned types of investigations. An unclear risk of selection bias (owing to lack of information regarding the randomization procedure, $\mathrm{n}=19$ and concealment, $\mathrm{n}=21$ ), performance bias (owing to lack of information regarding blinding of participants and personnel, $\mathrm{n}=18$ ) and detection bias (blinding of outcome evaluation, $n=21$ ) was noticed. The risk of bias for the studies was low for reporting bias and attrition bias ( $>$ Fig. 4 ).

\section{Discussion}

This is the first systematic review assessing the available literature on the effects of $N$. sativa on RA in in vitro, animal, and clinical studies. In vitro studies have noted the desirable effects of $N$. sativa in improving the inflammatory and oxidative status of RA $[46,47,72]$. Furthermore, almost all animal studies [46, 48$51,65-68,70,71]$ have shown that $N$. sativa and its active component TQ can have beneficial effects on clinical, inflammatory, oxidative, and immunologic parameters in RA. However, 2 studies in animal models $[56,69]$ did not report any significant effect of $N$. sativa in RA. In addition, human studies [52-56] have suggested favorable effects of $N$. sativa on clinical and immunologic parameters of RA; however, no change or improvement of inflammatory and oxidative biomarkers was declared in the clinical trials $[53,55]$. The controversy in findings between clinical and experimental investigations may be attributed to the differences in the measures of inflammatory, oxidative, and anti-oxidative markers in vivo or in vitro, as well as intensity and the type of stimulators of inflammation and oxidative stress. Furthermore, different preparations used in various studies may also affect the results. In clinical trials studied in this review, $N$. sativa oil was administered in capsules, whereas in a majority of experimental studies, the active component TQ was used. It seems that concentration of the principal compounds within N. sativa, namely TQ, varies greatly depending on the storage and preparation of $N$. sativa products, which can cause significant differences in bioactive compounds between studies. A primary limitation of the reviewed studies is the lack of information regarding quantification or standardization of bioactive compounds in the $N$. sativa preparations used. Standardization of herbal formulations is necessary in order to evaluate quality of drugs, based on the concentration of their active principles, physical, chemical, phytochemical, in vitro, and in vivo parameters [73]. Standardization of herbal medicines is the process of prescribing a set of standards or inherent features, constant parameters, and qualitative and quantitative values that carry an assurance of quality, efficacy, safety, and reproducibility [74]. However, among clinical trials and animal investigations reviewed here, only 1 study [70] discussed standardization of $N$. sativa preparation used. As mentioned above, TQ is the most bioactive component of $N$. sativa seeds and the oil that exists in tautomeric forms including the enol, keto and mixtures. Comprising the major fraction ( 90\%), the keto form is responsible for the pharmacological features of TQ [75]. TQ is a hydrophobic molecule, so its solubility can affect its bioavailability and cause limitations in drug formulation. In addition, its solubility depends on time as it ranges from $549-669 \mu \mathrm{g} / \mathrm{ml}$ in $24 \mathrm{~h}$ elevating to $665-740 \mu \mathrm{g} / \mathrm{ml}$ [76] in $72 \mathrm{~h}$. TQ can be consumed via various methods including oral, intravenous, and intraperitoneal. Oral administration of TQ can cause biotransformation due to the metabolizing liver enzymes that catalyzes TQ into a hydroquinone [75]. Not many reports are detectable regarding its oral pharmacokinetics, which can be due to its poor solubility and low oral bioavailability [77]. The clearance of TQ following intravenous administration is $7.19 \mathrm{ml} / \mathrm{kg} / \mathrm{min}$, and the estimated volume of distribution at steady state (VSS) is $700.90 \mathrm{ml} / \mathrm{kg}$. After oral administration, the apparent clearance value is $12.30 \mathrm{ml} / \mathrm{min} / \mathrm{kg}$, and VSS is $5109.46 \mathrm{ml} / \mathrm{kg}$. The absorption half-life (T1/2) of TQ is calculated about $217 \mathrm{~min}$, and it is rapidly removed from plasma [78]. The lack of bioavailability and pharmacokinetic parameters, as well as formulation problems, delayed the usage of TQ in the clinical phase. Thus, more investigations are required for a better understanding of TQ pharmacological properties meant for future clinical development.

Several potential mechanisms can be proposed for the observed ameliorating influences of N. sativa on RA. > Fig. 5 summarizes the potential mechanisms and pharmacological properties of 


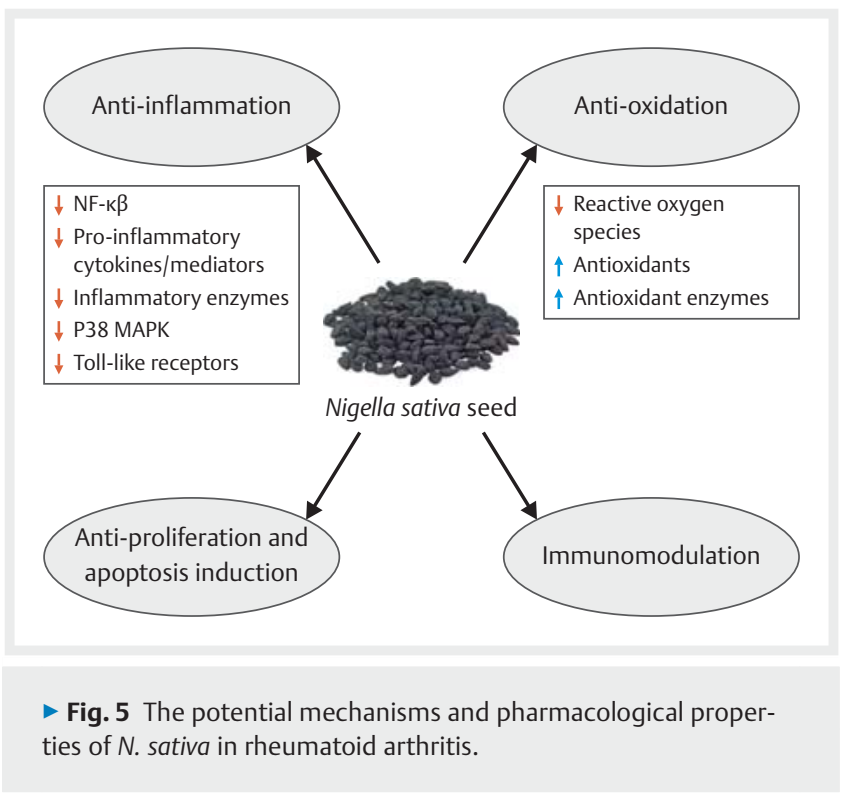

$N$. sativa in RA. The major bioactive component of $N$. sativa is the phytochemical TQ, which has been illustrated to convey anti-inflammatory, antioxidant, and immunomodulatory properties [48]. As noted previously, inflammation, oxidative damage, and immune system activation are major players in the development and progression of RA. Increased generation and activity of proinflammatory cytokines, specifically TNF- $\alpha$, IL-1, and IL-6, leads to the uncontrolled inflammation, which destructs the bone and cartilage and causes RA manifestations [79]. It has been suggested that the TQ in $N$. sativa can be involved in anti-inflammatory processes by preventing the production of eicosanoids such as thromboxane B2 and leukotriene B4 via suppressing COX and 5-lipoxygenase [80]. Furthermore, TQ can significantly inhibit the leukotriene C4 synthase activity [81]. In vitro treatment of stimulated neutrophils with TQ has shown to inhibit the generation of 5-lipoxygenase products and 5-hydroxy eicosatetraenoic acid [82]. TQ treatment in human blood cells can also inhibit the transformation of arachidonic acid to 5-hydroxy eicosatetraenoic acid [81].

In addition to the inhibitory effects of TQ on eicosanoid production, TQ has been proposed to retain its anti-inflammatory effects via inhibiting various pro-inflammatory transcription factors such as NF- $k$ B/STAT3, by inducing several stimuli including cytokines, free radicals, etc. [83]. NF- $\kappa B$ activation triggers multiple cascades that cause inflammatory and immune responses [79]. According to animal studies of inflammatory arthritis, NF-KB had a predominant function in expansion of arthritis [84]. Furthermore, NF- $\kappa$ B activation has been seen in RA synovial tissue in early as well as later phases [79]. Therefore, NF- $K B$ inhibitors are supposed to have therapeutic effects and are appropriate for RA treatment [85]. TQ can decrease pro-inflammatory responses predominantly by modulating NF- $\kappa \mathrm{B}$ activity and suppressing IL$1 \beta$, IL-6, TNF- $\alpha$, and IFN- $\gamma$ production [86-88].

Anti-inflammatory properties of $N$. sativa in RA are further supported by studies showing the preventive effects of TQ on the generation of NO [51]. NO is a pro-inflammatory mediator pro- duced from activated macrophages as part of the inflammatory response [89]. Inflammatory cytokines in chondrocytes can upregulate the activity of inducible nitric oxide synthase (iNOS) with the subsequent production of NO. The iNOS activity and plasma NO levels have been declared to be higher in RA cases compared with the normal controls $[90,91]$. Excessive NO production has been proposed in the induction of apoptosis in chondrocytes [92]. Thus, agents that prevent extra NO production may have helpful therapeutic influences on arthritis by blocking cartilage destruction [93].

Another possible mechanism for the observed positive effects of $N$. sativa in RA is its free radicals scavenging properties. TQ is a potent antioxidant scavenging reactive oxygen species (ROS) such as superoxide anion, hydroxyl radical, and singlet molecular oxygen $[28,94]$. The antioxidant activity of TQ may be attributed to the redox characteristics of its quinone structure and the capability of TQ to pass physiological barriers and easily reach the subcellular sections, all of which assist the radical cleaning function [95, 96]. Moreover, it can increase the activity of several antioxidant enzymes such as catalase, SOD, glutathione transferase, glutathione peroxidase, glutathione reductase, and GSH [97]. TQ may enhance the activation of Nrf2, and thus increase the heme oxygenase-1 (HO-1) expression [98].

The immunomodulatory activity of $N$. sativa is another possible mechanism through which it can influence RA. It has been indicated that $N$. sativa can enhance the immune response, particularly $T$ lymphocytes $[99,100]$, increase the proportion of helper T cells to suppressor T cells, and increase the activity of natural killer cells [101]. N. sativa has also been shown to modulate Th1/ Th2 pattern, and partially inhibit the Th2 [102]. Furthermore, a reduction in $\mathrm{B}$ cell-mediated immunity has been reported in vitro [103]. The immunomodulatory features of $N$. sativa and TQ have also been observed in mixed lymphocyte cultures, where it reduced IL-1 $\beta$ and IL-8 secretion [104]. Additionally, it has been announced that $N$. sativa can stimulate interleukin-3 secretion by T cells [105].

The first limitation of our study is the limited number of relevant clinical trials while the number of experimental studies is great and the majority of them have similar procedures. Due to lack of clinical trials and incomparable experimental information, we were not able to carry out meta-analysis on clinical, animal, and cellular studies. Furthermore, according to the risk of bias assessment, all experimental studies showed unclear risk of bias regarding randomization, allocation concealment, and masking ways because of the lack of reporting. Since the clinical investigations are often justified based on the findings from animal studies, this systematic review illustrated the need for randomization, allocation concealment, and masking outcome assessment of animal studies to reduce the risk of bias [106]. The strength of the present study was to systematically review all of the related human, animal, and in vitro studies. Furthermore, there was no limitation for time and language in our systematic review.

In this systematic review article, we tried to give persuasive clues on the efficacy of $N$. sativa in RA management and its mechanisms of function. Generally, there is an agreement regarding the impressive effects of $N$. sativa on clinical, inflammatory, oxidative, and immunologic parameters in animal models of RA, while 
the findings of the existing clinical investigations did not declare any change or improvement of inflammatory and oxidative biomarkers in RA subjects. Nevertheless, it should be noted that the majority of the animal research used $N$. sativa extract or its bioactive compound in high doses compared to $N$. sativa powder in clinical studies. In general, given the absence of sufficient clinical information, further randomized controlled clinical trials are warranted to confirm the promising effects of $N$. sativa on RA.

\section{Contributors' Statement}

Conception and design of the work: A. Khabbazi, Z. Javadivala, N. Seyedsadjadi, A. Malek Mahdavi; data collection: A. Khabbazi, Z. Javadivala, N. Seyedsadjadi, A. Malek Mahdavi; analysis and interpretation of the data: A. Khabbazi, Z. Javadivala, N. Seyedsadjadi, A. Malek Mahdavi; drafting the manuscript: A. Khabbazi, Z. Javadivala, N. Seyedsadjadi, A. Malek Mahdavi; critical revision of the manuscript: A. Khabbazi, Z. Javadivala, N. Seyedsadjadi, A. Malek Mahdavi.

\section{Acknowledgements}

The authors wish to thank the Connective Tissue Diseases Research Center of Tabriz University of Medical Sciences, Tabriz, Iran. We are also thankful to Dr. Ashraf Fakhari who helped us in drawing chemical structures.

\section{Conflict of Interest}

The authors declare that they have no conflict of interest.

\section{References}

[1] McInnes IB, Schett G. The pathogenesis of rheumatoid arthritis. N Engl J Med 2011; 365: 2205-2219

[2] Gibofsky A. Overview of epidemiology, pathophysiology, and diagnosis of rheumatoid arthritis. Am J Manag Care 2012; 18: S295-S302

[3] Lajas C, Abasolo L, Bellajdel B, Hernández-García C, Carmona L, Vargas E, Lázaro P, Jover JA. Costs and predictors of costs in rheumatoid arthritis: a prevalence-based study. Arthritis Care Res 2003; 49: 64-70

[4] Kumar P, Banik S. Pharmacotherapy options in rheumatoid arthritis. Clin Med Insights Arthritis Musculoskelet Disord 2013; 6: 35-43

[5] World Health Organization. WHO Guidelines on Safety Monitoring of herbal Medicines in Pharmacovigilance Systems. Geneva: Switzerland; 2004

[6] Kadhim M], Kaizal AF, Hameed IH. Medicinal plants used for treatment of rheumatoid arthritis: a review. Int J Pharm Clin Res 2016; 8: 1685-1694

[7] Salem ML. Immunomodulatory and therapeutic properties of the Nigella sativa L. seed. Int Immunopharmacol 2005; 5: 1749-1770

[8] Akram Khan M. Chemical composition and medicinal properties of Nigella sativa Linn. Inflammopharmacol 1999; 7: 15-35

[9] Al-Bukhari MI. The Collection of authentic Sayings of Prophet Mohammad (Peace Be Upon Him), Division 71 on Medicine. 2nd edition. Ankara: Hilal Yayinlari; 1976

[10] Ave-Sina AA. Law in Medicine. Tehran: Ministry of Guidance Publication; 1990: 314

[11] Junemann M, Luetjohann S. Three great healing Herbs: Tea Tree, St. Johns Wort, and Black Cumin. 1st edition. Twin Lakes, WI: Lotus Light Publications; 1998: 91-116
[12] Nergiz C, Ötles S. Chemical composition of Nigella sativa L. seeds. Food Chem 1993; 48: 259-261

[13] Cikman O, Ozkan A, Aras AB, Soylemez O, Alkis H, Taysi S, Karaayvaz M. Radioprotective effects of Nigella sativa oil against oxidative stress in liver tissue of rats exposed to total head irradiation. J Invest Surg 2014; 5: 262-266

[14] Burits M, Bucar F. Antioxidant activity of Nigella sativa essential oil. Phytother Res 2000; 14: 323-328

[15] Mousavi S, Tayarani-Najaran Z, Asghari M, Sadeghnia H. Protective effect of Nigella sativa extract and thymoquinone on serum/glucose deprivation-induced PC12 cells death. Cell Mol Neurobiol 2010; 30: 591-598

[16] Ghannadi A, Hajhashemi V, Jafarabadi H. An investigation of the analgesic and anti-inflammatory effects of Nigella sativa seed polyphenols. J Med Food 2005; 8: 488-493

[17] Islam MH, Ahmad IZ, Salman MT. In vivo evaluation of anti-inflammatory and analgesic activies of Nigella sativa seed during germination. Int J Pharm Pharm Sci 2013; 5: 451-454

[18] Mahmoud SS, Torchilin VP. Hormetic/cytotoxic effects of Nigella sativa seed alcoholic and aqueous extracts on MCF-7 breast cancer cells alone or in combination with doxorubicin. Cell Biochem Biophys 2013; 66: $451-460$

[19] Al-Sheddi ES, Farshori NN, Al-Oqail MM, Musarrat ], Al-Khedhairy AA, Siddiqui MA. Cytotoxicity of Nigella sativa seed oil and extract against human lung cancer cell line. Asian Pac J Cancer Prev 2014; 15: 983-987

[20] Hanafy MS, Hatem ME. Studies on the antimicrobial activity of Nigella sativa seed (black cumin). J Ethnopharmacol 1991; 34: 275-278

[21] Dey D, Ray R, Hazra B. Antitubercular and antibacterial activity of quinonoid natural products against multi-drug resistant clinical isolates. Phytother Res 2014; 28: 1014-1021

[22] Awad E, Austin D, Lyndon AR. Effect of black cumin seed oil (Nigella sativa) and nettle extract (quercetin) on enhancement of immunity in rainbow trout, Oncorhynchus mykiss (Walbaum). Aquaculture 2013; 388-391: 193-197

[23] Assayed ME. Radioprotective effects of black seed (Nigella sativa) oil against hemopoietic damage and immunosuppression in gamma-irradiated rats. Immunopharmacol Immunotoxicol 2010; 32: 284-296

[24] Meddah B, Ducroc R, El Abbes Faouzi M, Eto B, Mahraoui L, BenhaddouAndaloussi A, Martineau LC, Cherrah Y, Haddad PS. Nigella sativa inhibits intestinal glucose absorption and improves glucose tolerance in rats. J Ethnopharmacol 2009; 121: 419-424

[25] Zaoui A, Cherrah Y, Lacaille-Dubois MA, Settaf A, Amarouch H, Hassar M. Diuretic and hypotensive effects of Nigella sativa in the spontaneously hypertensive rat. Therapie 2000; 55: 379-382

[26] Ibrahim RM, Hamdan NS, Mahmud R, Imam MU, Saini SM, Rashid SN Abd Ghafar SA, Latiff LA, Ismail M. A randomized controlled trial on hypolipidemic effects of Nigella sativa seeds powder in menopausal women. J Transl Med 2014; 12: 82

[27] Ebru U, Burak U, Yusuf S, Reyhan B, Arif K, Faruk TH, Emin M, Aydin K, Atilla II, Semsettin S, Kemal E. Cardioprotective effects of Nigella sativa oil on cyclosporine A-induced cardiotoxicity in rats. Basic Clin Pharmacol Toxicol 2008; 103: 574-580

[28] Nagi MN, Mansour MA. Protective effect of thymoquinone against doxorubicin-induced cardiotoxicity in rats: a possible mechanism of protection. Pharmacol Res 2000; 41: 283-289

[29] Abdel-Sater KA. Gastroprotective effects of Nigella sativa oil on the formation of stress gastritis in hypothyroidal rats. Int J Physiol Pathophysiol Pharmacol 2009; 1: 143-149

[30] Mahmoud MR, El-Abhar HS, Saleh S. The effect of Nigella sativa oil against the liver damage induced by Schistosoma mansoni infection in mice. J Ethnopharmacol 2002; 79: 1-11

[31] Dollah MA, Parhizkar S, Izwan M. Effect of Nigella sativa on the kidney function in rats. Avicenna J Phytomed 2013; 3: 152-158 
[32] Hadjzadeh MA, Rad AK, Rajaei Z, Tehranipour M, Monavar N. The preventive effect of $\mathrm{N}$-butanol fraction of Nigella sativa on ethylene glycolinduced kidney calculi in rats. Pharmacogn Mag 2011; 7: 338-343

[33] Gilani AH, Aziz N, Khurram IM, Chaudhary KS, Iqbal A. Bronchodilator, spasmolytic and calcium antagonist activities of Nigella sativa seeds (Kalonji): a traditional herbal product with multiple medicinal uses. J Pak Med Assoc 2001; 51: 115-120

[34] Boskabady MH, Farhadi F. The possible prophylactic effect of Nigella sativa seed extract on respiratory symptoms, pulmonary function tests on chemical war victims. J Altern Complement Med 2008; 14: 11371144

[35] Boskabady MH, Mohsenpoor N, Takaloo L. Antiasthmatic effect of Nigella sativa in airways of asthmatic patients. Phytomedicine 2010; 17: 707713

[36] Hosseinzadeh H, Tafaghodi M, Mosavi MJ, Taghiabadi E. Effect of aqueous and ethanolic extracts of Nigella sativa seeds on milk production in rats. J Acupunct Meridian Stud 2013; 6: 18-23

[37] Hosseinzadeh H, Parvardeh S, Nassiri-Asl M, Mansouri MT. Intracerebroventricular administration of thymoquinone, the major constituent of Nigella sativa seeds, suppresses epileptic seizures in rats. Med Sci Monit 2005; 11: BR106-BR110

[38] Damião PD, Franklin FFN, Camila CMPS, Rubens BB, Ygor WV, Marciana PU, Timothy JB, Reinaldo ND. Anti-convulsant activity of thymoquinone and its structural analogues. Rev Bras Farmacogn 2011; 21: 427-433

[39] Perveen T, Haider S, Zuberi NA, Saleem S, Sadaf S, Batool Z. Increased 5-HT levels following repeated administration of Nigella sativa L. (black seed) oil produce antidepressant effects in rats. Sci Pharm 2014; 82: 161-170

[40] Kolahdooz M, Nasri S, Modarres SZ, Kianbakht S, Huseini HF. Effects of Nigella sativa $\mathrm{L}$. seed oil on abnormal semen quality in infertile men: a randomized, double-blind, placebo-controlled clinical trial. Phytomedicine 2014; 21: 901-905

[41] Hosseini M, Mohammadpour T, Karami R, Rajaei Z, Sadeghnia HR, Soukhtanloo M. Effects of the hydro-alcoholic extract of Nigella sativa on scopolamine-induced spatial memory impairment in rats and its possible mechanism. Chin J Integr Med 2015; 21: 438-444

[42] Al-Ali A, Alkhawajah AA, Randhawa MA, Shaikh NA. Oral and intra-peritoneal LD50 of thymoquinone, an active principle of Nigella sativa, in mice and rats. J Ayub Med Coll Abbottabad 2008; 20: 25-27

[43] Gali-Muhtasib H, El-Najjar N, Schneider-Stock R. The medicinal potential of black seed (Nigella sativa) and its components. Adv Phytomed 2006; 2: $133-153$

[44] Paarakh PM. Nigella sativa Linn. A comprehensive review. Indian J Nat Prod Resour 2010; 1: 409-429

[45] Ahmad A, Husain A, Mujeeb M, Khan SA, Najmi AK, Siddique NA, Damanhouri ZA, Anwar F. A review on therapeutic potential of Nigella sativa: A miracle herb. Asian Pac J Trop Biomed 2013; 3: 337-352

[46] Vaillancourt F, Silva P, Shi Q, Fahmi H, Fernandes JC, Benderdour M. Elucidation of molecular mechanisms underlying the protective effects of thymoquinone against rheumatoid arthritis. J Cell Biochem 2011; 112: $107-117$

[47] Umar S, Hedaya O, Singh AK, Ahmed S. Thymoquinone inhibits TNF- $\alpha$ induced inflammation and cell adhesion in rheumatoid arthritis synovial fibroblasts by ASK1 regulation. Toxicol Appl Pharmacol 2015; 287: 299_ 305

[48] Arjumand S, Shahzad M, Shabbir A, Yousaf M. Thymoquinone attenuates rheumatoid arthritis by downregulating TLR2, TLR4, TNF- $\alpha$, IL-1, and NF- $\kappa$ B expression levels. Biomed Pharmacother 2019; 111: 958-963

[49] Faisal R, Imran U. Comparative evaluation of thymoquinone and methotrexate in lung inflammation in murine model of rheumatiod arthritis. J Postgrad Med Inst 2015; 29: 88-92
[50] Tekeoglu I, Dogan A, Ediz L, Budancamanak M, Demirel A. Effects of thymoquinone (volatile oil of black cumin) on rheumatoid arthritis in rat models. Phytother Res 2007; 21: 895-897

[51] Umar S, Zargan J, Umar K, Ahmad S, Katiyar CK, Khan HA. Modulation of the oxidative stress and inflammatory cytokine response by thymoquinone in the collagen induced arthritis in Wistar rats. Chem Biol Interact 2012; 197: 40-46

[52] Kheirouri S, Hadi V, Alizadeh M. Immunomodulatory effect of Nigella sativa oil on T lymphocytes in patients with rheumatoid arthritis. Immunol Invest 2016; 45: 271-283

[53] Al-Okbi SY, Ammar NM, Soroor KHA, Mohammed DA. Impact of natural oils supplements on disease activity and antioxidant state of Egyptian patients with rheumatoid arthritis. Med J Islamic World Acad Sci 2000; 13: $161-171$

[54] Gheita TA, Kenawy SA. Effectiveness of Nigella sativa oil in the management of rheumatoid arthritis patients: a placebo controlled study. Phytother Res 2011; 26: 1246-1248

[55] Hadi V, Kheirouri S, Alizadeh M, Khabbazi A, Hosseini H. Effects of Nigella sativa oil extract on inflammatory cytokine response and oxidative stress status in patients with rheumatoid arthritis: a randomized, double-blind, placebo-controlled clinical trial. Avicenna J Phytomed 2016; 6: 34-43

[56] Mahdy A, Gheita T. Beneficial effects of Nigella sativa seed oil as adjunct therapy in rheumatoid arthritis. J Egypt Soc Toxicol 2009; 41: 31-37

[57] Mahboubi M, Taghizadeh Kashani ML, Mahboubi M. Nigella sativa fixed oil as alternative treatment in management of pain in arthritis rheumatoid. Phytomedicine 2018; 46: 69-77

[58] Gholamnezhad Z, Havakhah S, Boskabady MH. Preclinical and clinical effects of Nigella sativa and its constituent, thymoquinone: a review. J Ethnopharmacol 2016; 190: 372-386

[59] Tavakkoli A, Mahdian V, Razavi BM, Hosseinzadeh H. Review on clinical trials of black seed (Nigella sativa) and its active constituent, thymoquinone. J Pharmacopuncture 2017; 20: 179-193

[60] Yimer EM, Tuem KB, Karim A, Ur-Rehman N, Anwar F. Nigella sativa L. (black cumin): a promising natural remedy for wide range of illnesses. Evid Based Complement Alternat Med 2019; 2019: 1-16

[61] Moher D, Shamseer L, Clarke M, Ghersi D, Liberati A, Petticrew M, Shekelle P, Stewart LA; PRISMA-P Group. Preferred reporting items for systematic review and meta-analysis protocols (PRISMA-P) 2015 statement. Syst Rev 2015; 4: 1-9

[62] Higgins JP, Altman DG, Gøtzsche PC, Jüni P, Moher D, Oxman AD, Savovic J, Schulz KF, Weeks L, Sterne JA; Cochrane Bias Methods Group; Cochrane Statistical Methods Group. The Cochrane collaboration's tool for assessing risk of bias in randomised trials. BM] 2011; 343: 1-9

[63] Krithikadatta J, Gopikrishna V, Datta M. CRIS Guidelines (Checklist for Reporting In vitro Studies): A concept note on the need for standardized guidelines for improving quality and transparency in reporting in-vitro studies in experimental dental research. J Conserv Dent 2014; 17: $301-$ 304

[64] Hooijmans CR, Rovers MM, de Vries RB, Leenaars M, Ritskes-Hoitinga M, Langendam MW. SYRCLE's risk of bias tool for animal studies. BMC Med Res Methodol 2014; 14: 1-9

[65] Nasuti C, Fedeli D, Bordoni L, Piangerelli M, Servili M, Selvaggini R, Gabbianelli R. Anti-inflammatory, anti-arthritic and anti-nociceptive activities of Nigella sativa oil in a rat model of arthritis. Antioxidants (Basel) 2019; 8: 342-358

[66] Faisal R, Ahmad N, Fahad YS, Chiragh S. Anti-arthritic effect of thymoquinone in comparison with methotrexate on pristane induced arthritis in female sprague dawley rats. J Ayub Med Coll Abbottabad 2018; 30: 3-7

[67] Faisal R, Chiragh S, Popalzai AJ, Rehman KU. Anti-inflammatory effect of thymoquinone in comparison with methotrexate on pristane induced arthritis in rats. J Pak Med Assoc 2015; 65: 519-525 
[68] Faisal R, Shinwari L, Jehangir T. Comparison of the therapeutic effects of thymoquinone and methotrexate on renal injury in pristane induced arthritis in rats. J Coll Physicians Surg Pak 2015; 25: 597-601

[69] Hou W, Meng L, Zheng F, Wen Y, Zhu W, Jiang C, He X, Zhou Y, Lu S. Methotrexate ameliorates pristane-induced arthritis by decreasing IFN- $\gamma$ and IL-17A expressions. J Zhejiang Univ Sci B 2011; 12: 40-46

[70] Sajad M, Asif M, Umar S, Zargan J, Rizwan M, Ansari SH, Ahmad M, Khan HA. Amelioration of inflammation induced oxidative stress and tissue damage by aqueous methanolic extract of Nigella sativa Linn. in arthritic rats. J Altern Complement Med 2010; 7: 1-21

[71] Budancamanak M, Kanter M, Demirel A, Ocakci A, Uysal H, Karakaya C. Protective effects of thymoquinone and methotrexate on the renal injury in collagen-induced arthritis. Arch Toxicol 2006; 80: 768-776

[72] May M. The Role of Antioxidants (Gag S \& Tq) on the Viability and Proliferation of an Htb-93 rheumatoid Arthritis Cell Model [dissertation]. Jackson: Mississippi Medical Center University; 2007

[73] Bauer R. Quality criteria and standardization of phytopharmaceuticals: can acceptable drug standard can be achieved. Drug Info J 1998; 32: 101-110

[74] Sachan A, Vishnoi G, Kumar R. Need of standardization of herbal medicines in modern era. Int J Phytomedicine 2016; 8: 300-307

[75] Darakhshan S, Bidmeshki Pour A, Hosseinzadeh Colagar A, Sisakhtnezhad S. Thymoquinone and its therapeutic potentials. Pharmacol Res 2015; 95-96: 138-158

[76] Salmani JM, Asghar S, Lv H, Zhou J. Aqueous solubility and degradation kinetics of the phytochemical anticancer thymoquinone; probing the effects of solvents, $\mathrm{pH}$ and light. Molecules 2014; 19: 5925-5939

[77] Schneider-Stock R, Fakhoury IH, Zaki AM. Thymoquinone: fifty years of success in the battle against cancer models. Drug Discov Today 2014; 19: $18-30$

[78] Alkharfy KM, Ahmad A, Khan RM, Al-Shagha WM. Pharmacokinetic plasma behaviors of intravenous and oral bioavailability of thymoquinone in a rabbit model. Eur J Drug Metab Pharmacokinet 2015; 40: 319-323

[79] Kowshik Aravilli R, Laveen Vikram S, Kohila V. Phytochemicals as potential antidotes for targeting NF- $\kappa$ B in rheumatoid arthritis. 3 Biotech 2017; 7: $253-263$

[80] Houghton PJ, Zarka R, de las Heras B, Hoult JR. Fixed oil of Nigella sativa and derived thymoquinone inhibit eicosanoid generation in leukocytes and membrane lipid peroxidation. Planta Med 1995; 61: 33-36

[81] Mansour M. Tornhamre S. Inhibition of 5-lipoxygenase and leukotriene C4synthase in human blood cells by thymoquinone. J Enzyme Inhib Med Chem 2004; 19: 431-436

[82] El-Dakhakhny M, Madi NJ, Lembert N, Ammon HP. Nigella sativa oil, nigellone and derived thymoquinone inhibit synthesis of 5-lipoxygenase products in polymorphonuclear leukocytes from rats. J Ethnopharmacol 2002; 81: 161-164

[83] Woo CC, Kumar AP, Sethi G, Tan KH. Thymoquinone: potential cure for inflammatory disorders and cancer. Biochem Pharmacol 2012; 83: 443451

[84] Mor A, Abramson SB, Pillinger MH. The fibroblast-like synovial cell in rheumatoid arthritis: a key player in inflammation and joint destruction. Clin Immunol 2005; 115: 118-128

[85] Roman-Blas JA, Jimenez SA. NF- $\kappa B$ as a potential therapeutic target in osteoarthritis and rheumatoid arthritis. Osteoarthr Cartilage 2006; 14 : 839-848

[86] Sayed AA, Morcos M. Thymoquinone decreases AGE-induced NF-kappaB activation in proximal tubular epithelial cells. Phytother Res 2007; 21: 898-899

[87] Keyhanmanesh R, Boskabady MH, Eslamizadeh M], Khamneh S, Ebrahimi MA. The effect of thymoquinone, the main constituent of Nigella sativa on tracheal responsiveness and white blood cell count in lung lavage of sensitized guinea pigs. Planta Med 2010; 76: 218-222
[88] Bordoni L, Fedeli D, Nasuti C, Maggi F, Papa F, Wabitsch M, De Caterina R, Gabbianelli R. Antioxidant and anti-inflammatory properties of Nigella sativa oil in human pre-adipocytes. Antioxidants (Basel) 2019; 8: 51-62

[89] Seo WG, Pae HO, Oh GS, Chai KY, Kwon TO, Yun YG, Kim NY, Chung HT. Inhibitory effects of methanol extract of Cyperus rotundus rhizomes on nitric oxide and superoxide productions by murine macrophage cell line, RAW 264.7 cells. J Ethnopharmacol 2001; 76: 59-64

[90] Savnik A, Malmskov H, Thomsen HS, Graff LB, Nielsen H, DanneskioldSamsoe B, Boesen J, Bliddal H. Magnetic resonance imaging of the wrist and finger joints in patients with inflammatory joint diseases. J Rheumatol 2001; 28: 2193-2200

[91] Romas E, Sims NA, Hards DK, Lindsay M, Quinn JWM, Ryan PFJ, Dunstan CR, Martin TJ, Gillespie MT. Osteoprotegerin reduces osteoclast numbers and prevents bone erosion in collagen-induced arthritis. Am J Pathol 2002; 161: 1419-1427

[92] Blanco F], Ochs RL, Schwarz H, Lotz M. Chondrocyte apoptosis induced by nitric oxide. Am J Patholo 1995; 146: 75-85

[93] Shukla M, Gupta K, Rasheed Z, Khan KA, Haqqi TM. Bioavailable constituents/metabolites of pomegranate (Punica granatum L) preferentially inhibit COX2 activity ex vivo and IL-1beta-induced PGE2 production in human chondrocytes in vitro. J Inflamm 2008; 5: 9-18

[94] Mansour MA, Nagi MN, El-Khatib AS, Al-Bekairi AM. Effects of thymoquinone on antioxidant enzyme activities, lipid peroxidation and DTdiaphorase in different tissues of mice: a possible mechanism of action. Cell Biochem Funct 2002; 20: 143-151

[95] Badary OA, Taha RA, Gamal el-Din AM, Abdel-Wahab MH. Thymoquinone is a potent superoxide anion scavenger. Drug Chem Toxicol 2003; 26: $87-98$

[96] Daba MH, Abdel-Rahman MS. Hepatoprotective activity of thymoquinone in isolated rat hepatocytes. Toxicol Lett 1998; 95: 23-29

[97] Khalife KH, Lupidi G. Nonenzymatic reduction of thymoquinone in physiological conditions. Free Radic Res 2007; 41: 153-161

[98] Kundu J, Kim DH, Kundu JK, Chun KS. Thymoquinone induces hemeoxygenase- 1 expression in HaCaT cells via Nrf2/ARE activation: Akt and AMPK as upstream targets. Food Chem Toxicol 2014; 65: 18-26

[99] Swamy S, Tan B. Cytotoxic and immunopotentiating effects of ethanolic extract of Nigella sativa L. seeds. J Ethnopharmacol 2000; 70: 1-7

[100] Yehuda S, Carasso RL. Modulation of learning, pain thresholds, and thermoregulation in the rat by preparations of free purified alpha-linolenic and linoleic acids: determination of the optimal omega 3-toomega 6 ratio. Proc Natl Acad Sci U S A 1993; 90: 10345-10349

[101] Abdel-Zaher AO, Abdel-Rahman MS, Elwasei FM. Protective effect of Nigella sativa oil against tramadol-induced tolerance and dependence in mice: role of nitric oxide and oxidative stress. Neurotoxicol 2011; 32 : 725-733

[102] Işık H, Çevikbaş A, Gürer ÜS, Kiran B, Uresin Y, Rayaman P, Gürbüz B, Büyüköztürk S. Potential adjuvant effects of Nigella sativa seeds to improve specific immunotherapy in allergic rhinitis patients. Med Princ Pract 2010; 19: 206-211

[103] Haq A, Abdullatif M, Lobo PI, Khabar KS, Sheth KV, al-Sedairy ST. Nigella sativa: effect on human lymphocytes and polymorphonuclear leukocyte phagocytic activity. Immunopharmacol 1995; 30: 147-155

[104] Haq A, Lobo PI, Al-Tufail M, Rama NR, Al-Sedairy ST. Immunomodulatory effect of Nigella sativa proteins fractionated by ion exchange chromatography. Int J Immunopharmacol 1999; 21: 283-295

[105] Wu D, Meydani M, Leka LS, Nightingale Z, Handelman G], Blumberg JB, Meydani SN. Effect of dietary supplementation with black currant seed oil on the immune response of healthy elderly subjects. Am J Clin Nutr 1999; 70: 536-543

[106] Hirst JA, Howick J, Aronson JK, Roberts N, Perera R, Koshiaris C, Heneghan $C$. The need for randomization in animal trials: An overview of systematic reviews. PLoS One 2014; 9: 1-11 